\title{
Female Socio-economic Conditions and Feminization of Poverty in Rural Areas of District Larkana of Sindh, Pakistan
}

\author{
Ghazala Panhwar ${ }^{1}$, B. Faika Tahir ${ }^{2}$, and Shabana Tunio ${ }^{3}$
}

\begin{abstract}
This paper explores out the relation of feminization of poverty and education as well as the devaluation of the female workforce. Feminization of poverty is a global phenomenon and the prominent in underdeveloped countries. Pakistan does not have any concrete data on the female workforce or feminization of poverty. The ethnological methods were adopted to find out the changes over time. However, such the data acquired through focus group discussion, in-depth interviews, and participant observations. The study aimed to understand the feminization of poverty through the lens of feminism theory. The effect of education was observed. The study shows that the devaluation of female work is more prominent in uneducated female and female-headed households than educated females and male-headed households. The difference between a male and female household and their wage difference was also underpinned in the study. The educated female who was economically independent possessed and heightened confidence level important position in the family as compared to uneducated females. Education had a positive impact on female empowerment and self-awareness. Social norms of rural areas influenced female behaviors towards jobs and earnings. The study examines the everyday life of women in district Larkana. The narrative points out the feminization of poverty and the vicious cycle of poverty in females due to lack of education and low-paying jobs.
\end{abstract}

Keywords: Feminization of poverty; Devaluation of female work; Female life; Education.

\section{Introduction}

Feminization of poverty may be described as the economic dichotomy based on gender. This concept is being around since the late '70s (Medeiros and Costa, 2008). Feminization of poverty is a global phenomenon. Women worldwide, especially in underdeveloped countries, and suffer more from poverty than men. The several social and economic factors hinder women from achieving financial stability. The majority of women are housewives, and males work as breadwinners, making women dependent on males. The hindrance includes lack of education and market-oriented skill development, women's involvement in unpaid domestic work, childbearing and rearing,

\footnotetext{
${ }^{1}$ Department of Sociology, University of Sindh, Jamshoro, Sindh, Pakistan.

${ }^{2}$ Department of Sociology, University of Sindh, Jamshoro, Sindh, Pakistan.

${ }^{3}$ Department of Sociology, University of Sindh, Jamshoro, Sindh, Pakistan.
}

*)Corresponding Author.

Email: ghazal.panhwar@usindh.edu.pk 
social restrictions for specific jobs; family pressures to work with males and so forth. Females are low-paid workers in most careers as compared to males, which keep them economically in a disadvantaged position. Most women in rural areas stay at a home or earn handicrafts or sometimes win from farm cultivation or become a cheap labor force in fields, and women are paid meager wages.

The world population is over 7 billion, and 1.3 billion people live under the poverty line (Global Poverty facts, 2021). Poverty has a female face, and women form a significant share in poverty statistics, consisting of $70 \%$ of the 1.3 billion. The relevant studies showed a substantial cause of women's poverty is lack of education, exceedingly market-oriented education, and due to this: they are not eligible to get highly paid jobs. Unskilled and uneducated women are more affected by poverty as compared to men. Lack of marketoriented education constrains women from being involved in low-wedged labor or remaining unemployed. Thus, the cycle of dependency remains intact, and women, if they join the workforce stays at lower-paid jobs.

In today's modern world importance of education cannot be denied. Education is a fundamental skill to survive in science and technology. United Nations declared education is the absolute right for all without the discrimination of age, sex, race or class and so on. The importance of education increases with a market-oriented economy, globalization, and modernization.

Pakistan is an underdeveloped country struggling to fight terrorism, political instability, energy crisis, and many more. According to the Ministry of Finance Report 2018, the overall literacy rate in Pakistan has decreased from $60 \%$ to $58 \%$ in one year. Women are less access to educational institutions as compared to men. Only $2.2 \%$ federal budget is spent on education

The women's literacy rate is low due to the several reasons. Living under patriarchal values; the parents do not give equal importance to girls' education as compared to boys. In rural areas, girls help in house chores, rearing up younger siblings, grass cutting, cattle grazing; and assisting mothers to cook. It is still a cultural norm, though weakening, to keep girls at a home and allow boys to get an education. It is considered that girls are meant to organize and take care of the home while boys are future breadwinners. In this way, the girls remain unprivileged. Early marriage keep girls economically dependent on their husband. This cycle keeps the uneducated females financially dependent submissive, and unskilled for the market economy. International literature corroborated a strong association between education and female empowerment. The overall, there is a lack of focus on female education and literature scarcity targeting gender dichotomies in education.

\section{Background of Feminization of Poverty}

Feminization of poverty can be divided into two standards. The first, where women support themselves and their family without dependency on male 
members and face inequality in remunerations as compared to the male workers, the second is overall women inequality and bias that women face wedges as supportive breadwinners of a family (Goldberg and Kremen, 1990). This indicated the high-income discrepancy between males and females and male and female-headed households (Medeiros and Costa, 2008). The ruminations are low in female-dominated occupations and higher in maledominated fields (Mandel, 2013). The various factors that exacerbate the feminization of poverty include lower education attainments, age, sex dichotomy, societal norms that hinder female economic participation (Wienclaw, 2011). The factors that affect women's contribution to the workforce are the numerous according to their social and economic circumstances, and they differ in the modern age from the old era (Goldberg and Kremen, 1990). Even in industrial countries, feminization of poverty is not addressed on priority by policy-makers (Townson, 2000). The severity of the situation is not fully comprehended as the feminization of poverty contributed many factors yet to be explored (Wienclaw, 2011). The heterogeneous nature of female-headed households made it challenging to measure the feminization of poverty (Global Poverty, 2021). Ray, in his study, shows that there is a difference in dynamics in the feminization of poverty between Pakistan and South Africa. In South Africa, women are affected by the feminization of poverty per capita, which is the different from Pakistan, where the feminization of poverty is multidimensional. The factors include household size, intrafamilial resource allocation, and the adult-to-child ratio (Ray, 2000). Khalid and Akhter further examined these dynamics in their study Poverty Dynamics of Female-headed Households in Pakistan: The evidence from PIHS 2000-01 and PSLM 2004-05 and identified that these dynamics include that in the female-headed households, the poverty level does not decrease as compared to the overall poverty level. This can be attributed to the fact that earnings as the foreign remittances alleviate poverty- are received by more than $70 \%$ of female-headed households. In 2004-2005, Poverty among Female-headed homes did not decline as quickly as among mixed families nationwide from 2000-01 to 2004-05. It did not decrease at all in urban areas. They also found the primary cause among the poverty determinants of Female-headed households were illiteracy, dependency, and rural residence exacerbate poverty (Khalid \& Akhtar, 2011).

Women in Pakistan are less privileged and deprived of the essential health, maternity care, and education (Hameed et al., 2021). The lack of workforce participation of Pakistani females has its socio-cultural dynamics. Pakistani society encourages a joint family system, where two-three generations live together. Clan and the tribal system has still stronghold in rural areas. Where patriarchy could be seen in an extreme form. Females are not allowed by the family elders to participate in the workforce (Ali, 2017). According to the labor force participation survey 2014-15, the female workforce participation is as little as $22 \%$ compared to the male participation of $67.8 \%$. A majority of these women work in the agriculture sector (Pakistan 
Bureau of Statistics, 2015). Every government in Pakistan initiates some programs to address women empowerment issues (Pakistan Bureau of statistics, 2015).

\section{Research Methodology}

The research was conducted through the qualitative research methods. The data were collected through in-depth interviews, focus group discussions, and participant observation methods. The long-term ethnological- method is used to observe the data and the change of perspective in participants over time. This study was conducted in rural areas of Larkana, mostly underprivileged and neglected. Participants were divided into two groups, i.e., educated and uneducated women. Two groups were further sub-divided into employed and unemployed women. All the women responded satisfactorily to queries. The impacts of education on women were observed. This research generates the unique data and previously not obtained from the area. The current study focuses on women's education and its effects on their economic independence and the rumination; they earn. This study explores out the conditions of female-headed households and how education affects the educated and uneducated females participating in household economics. This study questions whether schooling facilitated women's involvement in decisionmaking and liberty to choose life partners. Whether educated women have access to more improved occupations and improved earnings, whether educated women have more awareness of social issues, law and order family planning.

\subsection{Limitations}

The study as limited to a specific area of the District Larkana, along with the limited respondents, so the results may differ if applied to a large population. We could not compare the wage gap between males and females on a large scale, so that the results may have also differed regarding the larger target population group. The respondents of the area were women, mostly uneducated, were not aware of the importance of such the study, and were a bit reluctant to cooperate. It was observed that females were not the comfortable with questions of personal information like family planning, spouse selection, and their answers carried ambiguity. It was the difficult to access all women of the area. Most women, especially uneducated females, were not aware of human rights. Thus, they could not identify whether their rights were provided or not. As in the District Larkana, the tribal system has a firm hold. The result might be the different in other provinces, where women possess more freedom and economic independence.

\section{Theoretical Framework}

The research is based on a feminist perspective. The feminist perspective asserts that gender is a social marker that affects both sexes, but negatively affects women without discriminating its social class or ethnic background. 
The effect of poverty is more visible on a female as $60 \%$ to $70 \%$ of the poor population worldwide is female, and the figures have not significantly changed since half a century.

The devaluation theory, also known as the comparable worth discrimination paradigm, assumes that females are culturally devalued in social structure. Their work is valued less than male members of society (Magnusson, 2009). The feminization of poverty cycle remains intact as women are left out to high-paid jobs due to less education or market-oriented education. Women's work produces less economic value in exchange for their services Wages paid to women workers are less than the time and energy they put in during job hours. Fabian Ochsenfeld's (2014) study on germen graduate students' data concluded that jobs traditionally done by males produce many economic rewards as compared to female employment, and there is a link between gender and monetary rewards. The devaluation of women's work can be divided into two forms when women's careers generate less economic rewards and traditionally feminine tasks are devalued because it is linked to women (P. England 1992, cited as Magnusson C., 2009). While some studies like Brynin and Perales (2016), pointed out that the wage gap between men and women decreased over time in the united kingdom between 1993 to 2008, especially in a workforce where education is required as a critical skill, educated graduate women enjoy equal benefits in fixed-effects jobs, while it indicates the negative effect of feminization on men in women-oriented positions (Brynin and Perales, 2016).

\section{Research Questions}

Research questions were set as bellow:-

- How does Education affect the lives of women in the District Larkana?

- Is there a wage gap between men and women and educated and uneducated women in the District Larkana?

- What are the causes of poverty in the female-headed household?

- Is there a change in female condition over time?

Research questions were set out to observe the changes over time to collect data for analyzing the difference in living conditions of women who got an employed or set up their own business after getting an education and the women who are working on their family farms or family livestock farming or working as a daily wage worker on other farms.

This is a famous proverb in local languages that if you have money, then visit Larkana. Once, Larkana was the province's most developed and cultural hub. This district is the unique because its population is politically active. After all, the top leadership of the major political party belongs to Larkana. However, this city no longer enjoys its glory due to political and administrative negligence and still lacks its due share in development. 
Larkana has famous tourist sites. The historical area of one of the oldest civilizations of "Moen jo Daro" traces back to $2500 \mathrm{BC}$. The famous Bhutto family mausoleum is also situated in Larkana, where former Prime Minister :Zulfiqar Ali Bhutto and his daughter, former Prime Minister of PakistanBenazir Bhutto, with other deceased family members, are buried here.

According to the Pakistan Bureau of statistics official website, the population of district Larkana is 1524391 with 261331 households. 54\% of the population lives in a rural area, while $46 \%$ lives in cities. $51 \%$ of the population is male, while $49 \%$ consists of females. The literacy rate (10 years of education) is $35 \%$, the male literacy ratio is $48.57 \%$, and the female literacy ratio is $20.48 \%$. Larkana is divided into four Talukas Bakrani, Ratodero, Dokri and Larkana itself.

Larkana is an agricultural-based district. The main crops cultivated hereare sugarcane, rice maze, sweet peas; Guava is the primary and quality production of Larkana.

The language spoken here is Sindhi, but Urdu is also spoken and understood. Educated people can communicate in English too. In rural areas, most of the population is involved in farming, and cattle farming waged labor, some works as small factories workers and government employees.

The interview participants were categorized as based on their educational level and role, sole breadwinner or supportive. The respondents were from the different village's union councils of district Larkana. The respondent population was 250 women of these villages.

\section{Results and Discussion}

FGD and in-depth interviews indicated a considerable positive change in women's condition, working in the private and public sectors. The working woman also exhibited an elevated level of confidence. They pose a higher level of self-reliance by earning their income, affecting their minor daily life decision-making. However, the primary decision making still influenced by male dominance.

A working woman also leaves a positive effect on enlightenment on their families. The majority of respondents were uneducated. We divided education on the basic education.

1. Primary education (five years of education)

2. Matriculation (Ten years of education)

3. Intermediate (Twelve years of education)

(Uneducated females who had never been to the formal education system could not read and write.

Most of the respondents on the study site worked on family farms, livestock farms, or other farms as daily wage labor. More than half of the women who possess twelve years of education ( $\mathrm{n}=55$ out of 95 formal degree holders) were involved in public sector jobs (Seven government school teachers, Thirteen private school teachers, Eighteen Local health visitors, 
Eleven working in factories as desk clerks or supervisors, Two as local union council members The gender-based wage difference was visible in uneducated females, i.e., hospital sweepers, cooks, etc. They were discharging the same obligation with the same working hours as a male worker, but were paid less. These wage differences directly affect female-headed households. They were visibly poorer than the male-headed households. The female-oriented and low cadre jobholders also complained about comparably lower salaries than males. The female-headed houses suffer more poverty because the source of income and also the means of income are limited for females.

A Lady Head of the family describes the wedge difference

\begin{abstract}
Hmm... It becomes the difficult to earn livelihood for family, you know.., when you are female and head of the family, you cannot feed all family members due to limited jobs for females in the market. I am working as a sweeper in a private hospital, and there is a difference between male sweeper salary and female sweeper salary in hospitals. Although we work for the same hours, we are paid less than male sweepers.
\end{abstract}

A lady who is working as a cook at a house asserted the same situation

I work as a housemaid and a cook. I am uneducated and have no other skills that help me get a job and feed my children; I get almost half of the pay as compared to male house help. And it is common wherever I go. Male cooks are getting the double salaries as compared to female cooks, and the same goes for house help. So a male doing a similar job can earn the double as I can get working the same amount of time.

While women working as house help or sweepers complain about the wage gap, women working in farms and fields admit that they are paid equal wages working on a farm for cotton plucking, grass cutting, sowing, and reaping the crops. Their work hours are similar to men's, paid daily. They have to wake up earlier than men because they must do their house chores before leaving for work. Most of these women were married, having more than three children on the average, and working because their husbands and in-laws were not earning the sufficient. Their contribution to earrings makes life somehow easier. Most women explained that they usually don't keep their earnings and spend them on the family. Still, they don't have a say in family decisions and are considered "unwise" and naive.

Educated women are in a better position. Women who are employed in government sector jobs are more satisfied. A female schoolteacher working in a government-run school describes it as;

I am very proud that I was among the first few girls of our village who got an education till graduation. There were so many hurdles created by family and relatives when I got an education. People 
used to say to my father that if you let his daughter get an education, she will become disobedient to the family and eventually will elope with some unknown man and shame the family. But thankfully, I convinced my father and completed my education. My family decided to marry my maternal cousin, and he is also educated, and I was happy with that proposal. We have been married for five years now. Unfortunately, he didn't get a job, while I got a government teacher job. I am running my house, and my husband is still searching for a job. It is challenging to manage the house and work, but it is considered a prime obligation for a woman to look after the family and home. It's challenging to handle, but I cannot leave my job as it is our family's sole source of income.

The female head of a family describes this as:

I was married young at the age of 19 years. Unfortunately, my husband died when I was just 24 with three children. My husband worked as an electrician; we were not prosperous, but were not worried about the next meal. After his death, our economic conditions deteriorated grossly. My in-laws refused to support me because they had their own families to feed with a meager income. I was educated, so I started teaching in a local school, and they paid me 1500 rupees per month. This amount was not the sufficient to feed my children. Somehow, I managed to get a job in Health and population department on a contract basis. My first salary was Rs. 1900 per month. Job profile includes visiting the different areas and educating women about childbirth, contraception, health, and vaccination to mothers and children. Also, we have to see several houses a day to administrate polio drops and vaccinations. I was happy that my salary increased, and I supported my children. Although my salary was not up to the mark of the standard earnings, I find it satisfactory and easy to work as a local health worker. Lady health worker job is a less paying because most of the workers are women, and they settle for less pay because of their financial needs.

Female handicraft workers are another example of low salaries. The majority of them are working in homes. They are involved in thread work on clothing, patchwork, cushion making, purse, and beads jewelry makings. The female worker of hand embroidery maintained that

I am uneducated. I work to bear my expenses and help the family as well. I do house chores in the day and work in the evening on my projects. It takes me a week to make an average embodied shirt and almost a month to complete suit with. I sell that to the middleman who sells to shopkeepers. I earn between Rs.500 to 1500 per piece 
of embroidery. Rating is not appreciable in terms of efforts and material used to make the suits. And the shopkeepers sell it for a considerable profit. I cannot sell it myself as I don't have access to the city due to cultural norms. I have been working on handicrafts for the last ten years and still cannot afford to buy myself new clothes for Eid celebrations; I try to buy clothes for my children.

All the women maintained that they work outside to earn a living, but they also help in house chores like cooking, cleaning the house, etc. The situation was worse for women who kept livestock at home. They do not get any share from the earnings, and they do not consider themself as working women. They include this work as a house chore which is undoubtedly not considered rumination work.

Women who were the head of family and earned similar to men also complained about the expenditure differences in the household. The expenditure is different due to the safety and security issues related to female movement back and forth from their work to home. Women usually avoid going outside in the evening, and they also take transports which is safer for females.

Table 1.

\begin{tabular}{|l|l|r|r|r|r|r|}
\hline \multicolumn{7}{|c|}{ Respondent Education * Source of Income Cross tabulation } \\
\hline Count \\
\cline { 3 - 8 }
\end{tabular}

Sources: Survey Data 
Table 2.

\begin{tabular}{|c|c|c|c|c|c|}
\hline \multicolumn{6}{|c|}{ Respondent Education } \\
\hline & & Frequency & Percent & $\begin{array}{c}\text { Valid } \\
\text { Percent }\end{array}$ & $\begin{array}{l}\text { Cumulative } \\
\text { Percent }\end{array}$ \\
\hline \multirow[t]{5}{*}{ Valid } & Primary / Middle & $\overline{52}$ & 20.8 & 20.8 & 20.8 \\
\hline & Matric / Inter & 63 & 25.2 & 25.2 & 46.0 \\
\hline & $\mathrm{BA} / \mathrm{MA}$ & 32 & 12.8 & 12.8 & 58.8 \\
\hline & $\begin{array}{l}\text { Nonformal/Illiter } \\
\text { ate }\end{array}$ & 103 & 41.2 & 41.2 & 100.0 \\
\hline & Total & 250 & 100.0 & 100.0 & \\
\hline
\end{tabular}

Sources: Survey Data

\section{Discussion}

As data presented in table No.1 pointed out a wage gap among females who have formal education and uneducated and skillful females working in the economic sector as skilled workers. The education of females directly or indirectly influences the means of earnings. Females who were head and sole earners of a family suffered more economic problems than females who supported the family. Both categories of females face the same issues while choosing a job. Most females were not allowed to work outside the house premises. So their choices were limited with meager earnings. Young females were more educated. But literacy rate was not encouraging. Abject poverty was a common in both educated and uneducated women. It was observed that women who work on their family farms or are involved in the family business of livestock farming don't consider themselves workers and consider themselves homemakers. They do not get any rumination for their services, and they believe it includes house chores or their daily responsibility. The devaluation of women's work was visible in family farmworkers, family livestock farmworkers, and handcraft workers.

During the FGD session, it is evident that women who work as a handcraft, patchwork, hand embroidery work for countless hours, and their final product don't cost much in markets. They do not have direct access to the market and are still dependent on the middleman.

Women who were the head of the family are relatively poorer it becomes challenging to meet the daily ends. Job options are limited for them. Those who acquired higher education were comparatively better positioned than their other counterparts. Female-headed households suffer more poverty due, lack of education and professional skills, social norms that hinder female mobility, and sometimes devaluation of their skills. They also complained about expending more than men as they avoid the risk associated with a single female safety in the society. They indicated to pay more on safe transport, trusted workers, and spending on house safety maintenance.

The research site consists of rural areas. So, living patterns and approach to the market was almost similar but, the educated females were 
comparatively in better condition than the uneducated women. Table No. 2 shows educational level of respondents participated in research. The research task showed that education helps women get better occupations and freedom to work. Educated women were engaged in government and private sector jobs. The study indicates the positive effects of female education on family affairs and decision-making. Uneducated women showed no involvement in family decision-making and remain dependent on others for their fate. Women also mentioned the liberty to select a life partner after getting an education. Research work revealed that education directly or indirectly impacts women's improved financial conditions. Educated females also identify family restrictions towards education on security or family conditions. Still, parents' limitations had adamantly received an education, positive acclivity permeated rural areas. The research task also found that uneducated women had no awareness of fundamental human rights and very little knowledge of NGOs. This lack of education complicates their lives, oblivious to rights and privileges. This study illuminated that education brings out the positive change in women's life. She can handle a family's needs more efficiently and can be helpful in the family economy rather than dependent on others. The study found a positive correlation between female education and empowerment.

\section{Conclusion and Recommendations}

1- Female-headed household which gets remittance from abroad- should not be included in the feminization of poverty reports since it may cause a discrepancy in the results and cloud the actual situation of female workers with low earnings. Hence, there is a need to rethink about what is the face of feminization of poverty pertinent to Pakistani society.

2- There should be studies on the expenditure of female-headed households as compared to a male-headed household with the same income.

3- Female education in rural areas is making the positive changes in the female agency. Thus, further investigation is necessary on which mode of education is more beneficial for women to secure jobs.

4- Educational standards should be directed to modern skill development. Since there are no industry-based jobs in rural areas, it is better to focus on skill development pertinent to that area's job market, which is the more generative for cottage industries. To enhance resource utilization effectively and reduce time and money waste.

5- The study suggests that with the help of modern technology, the void in jobs for females can be filled through job-oriented education.

6- Employment guarantee after education without gender discrimination would help attract more females towards education. 
7- Syllabus should be introduced according to job market-driven skill development that can help females get jobs near their homes and bolster the local economy.

\section{Notes}

Women under study were of rural areas, whose opinions highly influenced by that area's the overall societal and cultural dynamics. Women participants for the longitudinal study were observed, and the changes as noted. But a few of participants were not accessible after some time. Seven focus group discussion participants migrated to the big cities like Karachi and Hyderabad. Only the change in their financial conditions was collected through some reliable sources. Women under the study were observed after some time. There are positive changes in females who earn more than $\$ 100$ a month. They were physically and socially more active than the women who worked on farms or cattle farming. The difference between women working on their family farms and women who work as daily waged labor on other farms was not the significant.

\section{References}

Ali, F., 2017. R reasons for the Lack of Women's s Participation in Pakistan's Workforce 3, 99-102.

Brynin, M., Perales, F., 2016. Gender Wage Inequality: The De-gendering of the Occupational Structure. E R. Sociol. Rev. 32, 162-174. h tps://doi.org/10.1093/esr/jcv092

Global poverty: Facts, FAQs, and how to help. (2021, August 23). World Vision. https://www.worldvision.org/sponsorship-news-stories/globalpoverty-facts

Goldberg, G.S., Kremen, E., 1990. The feminization of poverty only in America? Preger Publishers, 88 Post Road West, Westport, CT 06881, Westport.

Hameed, W., Uddin, M., \& Avan, B. I. (2021). Are underprivileged and less empowered women deprived of respectful maternity care: Inequities in childbirth experiences in public health facilities in Pakistan. PloS One, 16(4), e0249874. https://doi.org/10.1371/journal.pone.0249874

Khalid, U., \& Akhtar, S. (2011). Poverty Dynamics of Female-headed Households in Pakistan: Evidence from PIHS 2000-01 and PSLM 2004-05. 25.

Magnusson, C., 2009. Gender, Occupational Prestige, and Wages: A Test of Devaluation Theory. Eur. Social. Rev. 25, 87-101. https://doi.org/10.1093/esr/jen035

Mandel, H., 2013. Up the down staircase: Women's upward mobility and the wage penalty for occupational feminization, 1970-2007. Soc. Forces 91, 1183-1206. 
Meiros, M., Costa, J., 2008. What Do We Mean by "Feminization of Poverty"? In "Poverty Cent. 36, 20-21.

Ochsenfeld, F., 2014. Why do women's fields of study pay less? A test of devaluation, human capital, and gender role theory. Eur. Sociol. Rev. 30, 536-548. https://doi.org/10.1093/esr/jcu060

Pakistan bureau of statistics, G. of P., 2015. Population , Labor Force and Employment. Pakistan Economic Survey 2014-15. Pakistan Bur. Stat. 235-255.

Ray, R. (2000). Poverty and expenditure pattern of households in Pakistan and South Africa: A comparative study. Journal of International Development, 12(2), 241-256. https://doi.org/10.1002/(SICI)10991328(200003)12:2<241::AID-JID654>3.0.CO;2-G

Shaukat, B., Javed, S. A., \& Imran, W. (2020). Wealth Index as Substitute to Income and Consumption: Assessment of Household Poverty Determinants Using Demographic and Health Survey Data. Journal of Poverty, 24(1), 24-44. https://doi.org/10.1080/10875549.2019.1678550

Townson, M., 2000. A Report Card on Women and Poverty by Monica Townson. A Report Card on Women and Poverty by Monica Townson.

Wienclaw, R.A., 2011. The effects of poverty and the welfare state, First Edit. ed. Salem Press, Pasadena, California. Hackensack, New Jersey. 